\title{
COMMENT ON CIVIL LAW AND COMMON LAW: TWO DIFFERENT PATHS LEADING TO THE SAME GOAL
}

\author{
Luke Nottage*
}

"Medio Tutissimus Ibis" ${ }^{* *}$

This comment attempts to place in broader context the article in this issue by Caslav Pejovic, "Civil Law and Common Law: Two Different Paths Leading to the Same Goal". The latter draws on several decades of his academic research and practical experience in navigating among differing legal systems, particularly in maritime law. This area of law requires an appreciation of both substantive and procedural law, how general principles come to be applied in evolving transactional contexts, and pressures towards - and sometimes against - the unification and harmonisation of normative frameworks. ${ }^{1}$

Not surprisingly, then, the core of his article surveys a wide range of issues where common law and civil law traditions begin, at least, with quite different approaches. Part III addresses points not only of contract law, but also property law and general commercial

* Jean Monnet Fellow, European University Institute Law Department, Barrister of the High Court of New Zealand. A much more detailed exposition of the conceptual framework presented in the latter half of this Comment is provided in L Nottage "Convergence, Divergence and the Middle Way in Unifying or Harmonising Private Law" (EUI Working Paper LAW No 2001/1, European University Institute, Florence, 2001, freely available at <http:/ / www.iue.it/PUB/EUI_WP.html>).

** "You will go most safely by the middle way": Ovid (43BC - AD17) Metamorphoses Book 3, I.466, translated in A Partington (ed) Oxford Dictionary of Quotations (4th new ed, 1992).

1 See also eg W Tetley "The General Maritime Law: The Lex Maritima" (1994) 20 Syracuse J Int'l L \& Comm 105; M Clarke "A Way With Words: Some Obstacles to Uniform Transport Law" [1998-2/3] Uniform L Rev 238. 
law, while Part IV deals with issues in civil procedure. ${ }^{2}$ After noting some tendencies towards convergence in outcome regarding several of these issues, Section 5 summarises some of the broader pressures drawing civil and common law closer together. Pejovic argues that the common law is increasingly hemmed in by legislation, including specific intervention as well as attempts to codify broad areas of law, while civil law jurisdictions increasingly rely on precedents set by the courts. ${ }^{3}$ The 1980 Vienna Sales Convention (CISG) promotes uniformity in substantive sales law. The partially overlapping UNIDROIT Principles of International Commercial Contracts advance broader harmonisation in contract planning and resolution of disputes involving more than just sales. Other normative frameworks bridging differences, such as those involved in the international commercial arbitration, are also mentioned. Finally, attention is paid to legal developments in the European Union, including the possibility of Principles of European Contract Law (PECL) elaborated by a study group headed by Professor Ole Lando being "upgraded" into a binding European Civil Code - a possibility, one should add, which has

2 Substantive law topics range from consideration or causa, contracts for the benefit of third parties, revocation of offers, frustration or force majeure, breach of contract and fault, notice of default, and liquidated damages; to transfer of property, trusts, mortgage or hypotheque; and bills of exchange. Except for these last two, these issues are discussed to a greater or lesser degree in A Hartkamp et al (eds) Towards a European Civil Code (Kluwer, The Hague, 2nd ed 1999). See also A von Ziegler et al (eds) Transfer of Ownership in International Trade (Kluwer, The Hague, 1999); and M Milo \& J Smits "Trusts in Mixed Legal Systems: A Challenge to Comparative Trust Law" (2000) 8/3 European Rev Private L 421 (in a very recent special issue on trusts). Procedural law topics considered by Pejovic address the degree of judicial initiative in civil proceedings, determination of facts, admissibility of evidence, witness statements, experts, and the effect of a criminal judgment on later civil proceedings. Recently, another maritime lawyer has identified an even broader range of differences in substantive and procedural law, arguably linked to differences in sources, concepts and style between civil and common law: contract interpretation, treatment of economic loss, pre-judgment interest, arbitration, general approach to the conflict of laws, forum (non) conveniens, and attitudes towards the lex mercatoria: see W Tetley "Mixed Jurisdictions: Common Law vs Civil Law (Codified and Uncodified)" [1999-3] Uniform L Rev 591, 615-9; [1999-4] Uniform L Rev 877-81 (also in (2000) 60 Louisiana L Rev 677).

3 See also D N MacCormick and R S Summers (eds) Interpreting Statutes: A Comparative Study (Dartmouth, Aldershot, 1993) and D N MacCormick and R S Summers Interpreting Precedents: A Comparative Study (Dartmouth, Aldershot, 1997). But compare J Bell "Comparing Precedent" (1997) 82 Cornell L Rev 1243. 
recently become much more real. ${ }^{4}$ Pejovic concludes that while some significant differences remain, which practitioners in particular need to be aware of, there is remarkable convergence or rapprochement between the common law and civil law traditions. Arguably, this is underscored by similarities in the subject matter of regulation and in underlying values.

In the final analysis, Pejovic therefore aligns himself with probably a majority view among contemporary commentators on unification or harmonisation of private law globally and, especially, in Europe. ${ }^{5}$ One characteristic of this scholarship is the focus primarily on convergence or similarities in actual results in particular litigated cases or the like (notably in the work of Basil Markesinis); ${ }^{6}$ in developing a "common core" of concepts

4 See generally G Alpa "European Community Resolutions and the Codification of 'Private Law'" (2000) European Rev Private Law 321; C von Bar "The Study Group on a European Civil Code" [4/2000] Tidskrift utgiven av Juridiska Föreningen i Finland (JFT) 323; but see J Wuermeling "Europäisches Privatrecht: Wider den Oktroi der Uniformität" [2001/3] Europarecht (forthcoming). In early 1998, a "Study Group on a European Civil Code" was formed, with membership overlapping with that of the Lando Commission, to develop proposals for codifying private law more broadly. This Group's Steering Committee includes Guido Alpa, Christian von Bar, Ulrich Drobnig, Roy Goode, Arthur Hartkamp, and Ole Lando. The EU's Council of Ministers subsequently expressed interest in this codification initiative, at meetings of Heads of Government in Cologne in early 1999 and Justice Ministers in Tampere in autumn 1999. The EU Commission has been charged with preparing a report on the issues involved, by the end of 2001, involving five of its Directorates. In parallel, the European Parliament has renewed discussions on this topic, having expressed interest in 1989 and 1994. A study commissioned and led by Christian von Bar has recently been published, covering needs and options for unification of general contract law, service contracts, insurance contracts, non-contractual obligations, consumer credit, and civil procedure. The Parliament is also consulting others, such as Christoph Schmid (a fellow at the European University Institute) on 21 November 2000. Further, a private project led by Guiseppe Gandolfi has already published the first part of a European Contract Law Code, modelled on the Italian Codice Civile: Académie des Privatistes Européens (ed) Code Européen des Contrats (1999). See C Schmid "Legimitaetsbedingungungen eines Europäisches Zivilgesetzbuchs" (56 Juristenzeitung, forthcoming 2001; also in English translation as Legitimacy Conditions for a European Civil Code, EUI Working Paper RSC 2001/5, EUI, Florence, 2001) Part I.

5 On the latter aspect, compare generally the survey by C Schmid "The Emergence of a Transnational Legal Science in Europe" (2000) 19 OJLS 673.

6 B Markesinis "Learning from Europe and Learning in Europe" in B Markesinis (ed) The Gradual Convergence: Foreign Ideas, Foreign Influences and European Law on the Eve of the 21st Century (Clarendon Press, Oxford, 1993) 1, 30; B Markesinis, "Judicial Style and Judicial Reasoning in England and Germany" (2000) 59 CLJ 294. 
derived from such comparisons (notably, the Trento project); ${ }^{7}$ in synthesising mainly doctrinal developments (Christian von Bar) ${ }^{8}$ and in promoting a broader legal "grammar" or shared vocabulary (Reinhard Zimmermann, ${ }^{9}$ or the "European Casebooks" project ${ }^{10}$ ). Another characteristic is attention to "the law in books" rather than the "law in action", despite some commentators (such as Hein Koetz) proclaiming the latter's importance in comparative research. ${ }^{11}$

Recently, however, vigorous counter-arguments have been presented which uncover and defend diversity and divergence. These often arise precisely regarding the Europeanisation (or otherwise) of private law, with Pierre Legrand (in)famously insisting on an irreducible differences between English common law and civil law on the Continent. ${ }^{12}$ However, such arguments raise or implicate issues in comparative law methodology more generally. Most adopt an expansive view of law, sometimes radically so - especially Legrand, 13 but also Hugh Collin's relatively early contribution to the

7 R Sacco "Legal Formants: A Dynamic Approach to Comparative Law (I)" (1991) AJCL 1, 4, 26-30, 32; M Bussani "'Integrative' Comparative Law Enterprises and the Inner Stratification of Legal Systems" (2000) European Rev Private Law 85; U Mattei "A Transactions Cost Approach to the European Civil Code" (1997) 5 European Rev Private Law 537; S Whittaker \& R Zimmermann, "Good Faith in European Contract Law: Surveying the Legal Landscape" in R Zimmermann \& S Whittaker Good Faith in European Contract Law (Cambridge UP, Cambridge, 2000) 7, 58; <http:// www.jus.unitn.it/dsg/common-core/>; and E Hondius "The Common Core of European Private Law, Trento, 15-17 July 1999" [2000] European Rev Private Law 249.

8 C von Bar The Common European Law of Torts, Vol 1: The Core Areas of Tort Law, its Approximation in Europe, and its Accommodation in the Legal System (Clarendon, Oxford, 1998). For a somewhat broader approach, more agnostic about convergence, see H Koetz \& A Flessner European Contract Law, Vol 1: Formation, Validity, and the Content of Contracts, Contract and Third Parties (T Weir trans, Clarendon, Oxford, 1997).

9 R Zimmermann "Savigny's Legacy: Legal History, Comparative Law, and the Emergence of a European Legal Science" (1996) 112 LQR 576;

10 W Van Gerven "Casebooks for the Common Law of Europe: Presentation of the Project" (1996) 4 European Rev Private Law 67; P Larouche "Ius Commune Casebooks for the Common Law of Europe: Presentation, Progress, Rationale" (2000) European Rev Private Law 101. W van Gerven et al (eds), Cases, Materials and Text on National, Supranational and International Tort Law (Hart, Oxford, 2000). One of the largest chapters in this casebook was published separately in 1998: Tort Law: The Scope of Protection (Hart, Oxford).

11 H Koetz "Comparative Law in Germany Today" [1999-4] RIDC 753, 755.

12 P Legrand "European Legal Systems Are Not Converging" (1996) 45 ICLQ 52; P Legrand "Against a European Civil Code" (1997) 60 MLR 44.

13 See also his essays and book reviews collected in: Fragments on Law and Culture (Willink, Deventer, 1999). More generally, see for instance V Curran "Cultural Immersion, Difference and Categories in US Comparative Law" (1998) 46 AJCL 43. 
Europeanisation debate. ${ }^{14}$ Gunther Teubner takes a more sociologically informed approach, which leads mainly to a stress on differences between English and continental European law, but some potential for "irritation" and co-evolution. ${ }^{15}$ Christian Joerges develops a more normative vision of law, seeing further evidence of - and scope for indirect cross-fertilisation primarily through the institutions of the European Union. ${ }^{16}$ Collins recently has taken more interest in the interaction between law and expectations or practices of businesses, although primarily only in England, in arguing for more generally stated principles to be included in any eventual unification of private law in Europe. ${ }^{17}$

At the risk of serious oversimplification, the primary orientation of the main commentators discussed above can be summarised along two dimensions, as depicted in the following Figure. One dimension is whether the primary focus remains on rules and the law in books, as opposed to the law in action. The former focus, covering the two main schools of comparative law scholarship already identified by Gunther Frankenberg by the mid-1980s, ${ }^{18}$ can be rephrased a "Rules-Plus" orientation. Although this allows for some variation in how much "plus" may be added to the comparative analysis of rules, a qualitatively and often quantitatively different orientation is evident among those who begin with an expansive view of "law in context". A second dimension is the extent to which these various commentators perceive - and, usually, advocate - similarities and convergence as opposed to difference and divergence.

14 H Collins "European Private Law and the Cultural Identity of States" (1995) European Rev Private Law 353.

15 G Teubner "Legal Irritants: Good Faith in British Law and How Unifying Law Ends Up in New Divergences" (1998) 61 MLR 11.

16 C Joerges "The Impact of European Integration on Private Law: Reductionist Perceptions, True Conflicts and a New Constitutional Perspective" (1997) 3 European LJ 378; C Joerges "Interactive Adjudication in the Europeanisation Process? A Demanding Perspective and a Modest Example" (2000) European Rev Private Law 1.

17 H Collins "Formalism and Efficiency: Designing European Commercial Contract Law" (2000) European Rev Private Law 211. See also H Collins "Quality Assurance in Subcontracting" in S Deakin \& J Michie (eds) Contracts, Co-operation, and Competition (Oxford UP, Oxford, 1997) 285.

18 Cf G Frankenberg "Critical Comparisons" (1985) Harv Int'l LJ 411, 430. 


\begin{tabular}{|l|l|l|}
\hline & Rules-Plus & Law in Context \\
\hline \multirow{3}{*}{ Convergence } & Lando (recently) & \\
Markesinis & \\
Zimmermann (recently) & Friedman \\
& Trento group & \\
Kötz (in practice) & Casebook project & \\
Zweigert/Kötz (in practice) & \\
\hline \multirow{2}{*}{ Divergence } & Collins (recently) & Joerges \\
& Teubner \\
& & Curran \\
& & Legrand \\
\hline
\end{tabular}

Crudely, to be sure, situating in this way the approach of these various comparativists first shows quite clearly that narrower views of law tend to be associated with a focus on convergence; and expansive views, with divergence. However, the correlation is neither a logical nor a necessary one. On the one hand, this is shown by the studies of Alan Watson, who analyses historical transplants of legal rules "out of context", yet is unafraid to discuss differences. ${ }^{19}$ On the other, Lawrence Friedman takes an expansive view of law as "legal culture", but stresses convergence even on a global scale. ${ }^{20}$

Secondly, this depiction should remind us that although "convergence theorists", focused mainly on the law in books, form now the majority view, a significant body of scholarship has developed explicitly or implicitly questioning both major premises of their work.

Thirdly, this conceptual framework and the present state of comparative law scholarship - mainly dealing with private law - suggest in the possibility of developing a

19 Arguably, Watson's writings have put this argument in both "strong" and "weak" versions, with only the former implying that the broader social context deserves no attention: see $\mathrm{W}$ Ewald "Comparative Jurisprudence (II): The Logic of Legal Transplants" (1995) 43 AJCL 489. However, Watson's subsequent writings eg The Evolution of Western Private Law (John Hopkins UP, 2000) indicate that he himself holds to the "strong" view.

20 L M Friedman "The Concept of Legal Culture: A Reply" in D Nelken (ed) Comparing Legal Cultures, (Dartmouth, Aldershot, 1997) 33; L M Friedman "On the Emerging Sociology of Transnational Law" (1996) 32 Stan J Int'l L 65; L M Friedman The Horizontal Society (Yale UP, New Haven (Conn), 1999). 
"middle way" along both dimensions. Ultimately, a comparative lawyer - qua lawyer must begin with some theory of what constitutes law, even if this comes to be reformulated in the light of an ongoing praxis in comparing legal systems. Few legal theorists now subscribe to a narrow positivist view of law as a system of rules, and many would add more to the picture than "Rules-Plus" comparativists. But few would conflate law with culture, morality, or the like. The middle way therefore justifies close attention to legal rules and normative discourse more generally, as well as their development and application in a range of institutional and transactional contexts which are often not usually defined - or explored - as "legal", at least by "Rules-Plus" comparativists. Broader analysis also makes it more likely that new complex relationships between these components will be uncovered. It may remain possible to summarise this in parsimonious theories, and we should recall that the admonition to "keep it simple" has long been the watchword of many (practising) lawyers as well as scientists and medieval clerics. ${ }^{21}$ But we should resist the tendency to oversimplify, ignoring or downplaying phenomena which cannot be readily explained. The "Rules-Plus" comparativists who advance strong claims of convergence appear to be falling into this trap, even after having delimited the scope of their enquiries through the various practices described above. Emerging debate on enactment of a European Civil Code may well bring this all to light. ${ }^{22}$

As noted already by John Henry Merryman at an early international conference held at the European University Institute (EUI), in 1977:23

In some cases the desire for convergence of legal systems merely expresses a yearning for simplicity. It responds to popular discontent with complexity and seeks to impose order where there is untidy diversity. This approach to legal diversity would hardly merit recognition and discussion, since it is little more than an expression of frustration at the fact that the world is complicated, disorderly and uncertain, were it not so firmly rooted in human psychology. It is closely related to an exaggerated demand for certainty in the law.

Thus, the wisest course for comparative private lawyers nowadays probably involves first addressing as much attention to (a) the exegesis of statutes, case law, and legal doctrine as to (b) underlying patterns of legal reasoning, with their supporting institutional infrastructure, and (c) how this interacts with the wider socio-economic context. Secondly,

21 Cf N Rescher Complexity: A Philosophical Overview (Transaction Publishers, New Brunswick, 1998) 61.

22 Above $\mathrm{n} 4$.

23 J H Merryman "On the Convergence (and Divergence) of the Civil Law and the Common Law" in his The Loneliness of the Comparative Lawyer and Other Essays in Foreign and Comparative Law (Kluwer, The Hague, 1999)17, 27; chapter reprinted from M Cappelletti (ed) New Perspectives for a Common Law of Europe (Sijtoff, Leyden, 1978) 195. 
this probably will involve differentiated appraisals of convergence and divergence. My own work has tried to follow both strictures, although doubtless with variable success. ${ }^{24}$ This would place me somewhere near the centre of the Figure above; my work probably draws closest to that of Joerges.

Taking "the middle way", in these respects, should hold a more universal appeal. The position was advocated not only by Ovid two millennia ago; moderation was advocated by both Solon and Gautama Buddha in the sixth century BC, and in a Japanese expression probably borrowed from China around this time; and now the British Prime Minister seeks

24 On contract law, see respectively (a) eg L Nottage, "Form and Substance in US, English, New Zealand and Japanese Law: A Framework for Better Comparisons of Developments in the Law of Unfair Contracts" (1996) 26 VUWLR 247; (b) "The Centennial of Japan's Civil Code and the Future of New Zealand Contract Law", paper presented at the Australasian Law Teachers Association conference, Victoria University of Wellington, 4-7 July 1999; (c) "Planning and Renegotiating Long-Term Contracts in New Zealand and Japan: An Interim Report on an Empirical Research Project" [1997] New Zealand L Rev 482, "Bargaining in the Shadow of the Law and Law in the Light of Bargaining: Contract Planning and Renegotiation in the US, New Zealand, and Japan" in J Feest \& V Gessner (eds), Interaction of Legal Cultures (Pre-publications of the Workshop on "Changing Legal Cultures", Oñati International Institute for the Sociology of Law, 1998) 113. On product liability and safety law, see eg (a) "Global Harmony and Disharmony in Accident Compensation: Japan's New Product Liability Legislation compared to the EC Directive and Part VA of the Australian Trade Practices Act" (1999) 66/2 Hosei Kenkyu F1; (b) "The Present and Future of Product Liability Dispute Resolution in Japan" (2000) 27/1 William Mitchell L Rev 215; (c) "The Still-Birth and Re-Birth of Product Liability in Japan" in J Feest \& D Nelken (eds), Adapting Legal Cultures (Hart Publishing, Oxford, forthcoming), and (with Y Wada) "Japan's New Product Liability ADR Centers: Bureaucratic, Industry, or Consumer Informalism?" (1998) 6 Zeitschrift fuer japanisches Recht 40 .

This has encouraged me to develop new dimensions in formal versus substantive reasoning, bringing out similarities between English and New Zealand law on the one hand, and US and Japanese law on the other (these two often still being seen as worlds apart); and the possibility of an emergence of "neo-procedural" elements apparent in all four systems, albeit perhaps to varying degrees and without requiring that this lead to convergence even over the long term (see "Proceduralisation of Japanese Law in Comparative Perspective: Product Liability and Contract", paper presented at the annual meeting of the Law \& Society Association, Chicago, 27-30 May 1999). However, because so much of the received wisdom from comparative lawyers - often unfamiliar with Japan (eg U Mattei "Three Patterns of Law: Taxonomy and Change in the World's Legal Systems" (1997) 45 AJCL 5, 28, 36-40; K Zweigert \& H Koetz Introduction to Comparative Law (T Weir trans, Clarendon, Oxford, 3rd ed 1998), 295-302) - stresses ostensible differences between "Western" and Japanese law, much of my writing on the latter has tried to balance this by identifying and scrutinising convergent elements and forces (see eg "Japanese Corporate Governance at a Crossroads" (Paper presented at the conference on "Economic Law Reform in the Aftermath of the Asian Crisis: Experiences of Japan and Thailand", Thammasat University, 20-21 March 2000, revised for proceedings edited by Thammasat University Law Faculty; and the revised paper with the sub-title "Variation in 'Varieties of Capitalism'?", presented at the University of Victoria, Canada, 14 February 2001, available through $<$ http://www.capi.uvic.ca/nottage/>). 
a "third way". ${ }^{25}$ But my great-grandfather - whose family emigrated from England to New Zealand via Australia - apparently used to urge "everything in moderation, including moderation", which the family has interpreted as allowing the occasional bout of extremism. ${ }^{26}$ And a German saying, popular in the student demonstrations in the 1960s, warns us that: "In danger and greatest need, the middle way leads to death". ${ }^{27}$ American political leaders are sceptical too. John Adams wrote in 1776 that "in politics ... the middle way is none at all", while George Shultz has cautioned recently that: "He who walks in the middle of the road gets hit from both sides". ${ }^{28}$ More divergence, as well as convergence, in Europe and world-wide! QED.

25 See respectively Ovid, above $\mathrm{n}$ **; "Nothing in excess" (also attributed to others around the 6th or 7th centuries BC: J Bartlett's Familiar Quotations (Little Brown, Boston et al, 16th ed 1992) 134); M Carrithers The Buddha (Oxford UP, Oxford, 1983) 72, 76; chuyo or "moderation"; T Blair The Middle Way: New Politics for the New Century (The Fabian Society, London, 1998). Thanks to Neil Walker and Seiji Morikawa for some of these.

26 This appears to be an interesting variation on the rather ambiguous saying attributed to the British politician, Benjamin Disraeli (1804-81): "There is moderation even in excess". See J Bartlett's Familiar Quotations (Little Brown, Boston et al, 16 ed 1992) 501.

27 "In Gefahr und grösster Not, führt der Mittelweg zum Tod." Thanks to Christian Joerges for this.

28 Quoted respectively in Bartlett, above n 26, 338; and K Mohler (ed) Webster's Electronic Quotebase (1994). Thanks to Peter Whisker for the latter. 
